\title{
25 Research Square \\ Ovarian Reserve in Nigerian Women with Sickle Cell Anaemia: A Cross-Sectional Study.
}

\section{Sunusi-Rimi Rimi Garba ( $\nabla$ sunusirimi@gmail.com )}

Lagos University Teaching Hospital https://orcid.org/0000-0002-0351-8302

\section{Christian Chigozie Makwe}

University of Lagos College of Medicine

\section{Vincent Oluseye Osunkalu}

University of Lagos College of Medicine

\section{Olufunto Olufela Kalejaiye}

University of Lagos College of Medicine

\section{Adaiah Priscillia Soibi-Harry}

Lagos University Teaching Hospital

\section{Amina Umar Aliyu}

Lagos University Teaching Hospital

\section{Bosede Bukola Afolabi}

University of Lagos College of Medicine

\section{Research}

Keywords: sickle cell anaemia, anti-Mullerian hormone, ovarian reserve, diminished ovarian reserve, ovarian sickling, hydroxyurea, haemoglobinopathy, Nigeria

Posted Date: May 14th, 2021

DOl: https://doi.org/10.21203/rs.3.rs-486227/v1

License: (c) (1) This work is licensed under a Creative Commons Attribution 4.0 International License.

Read Full License

Version of Record: A version of this preprint was published at Journal of Ovarian Research on December 1st, 2021. See the published version at https://doi.org/10.1186/s13048-021-00927-5. 


\section{Abstract}

Introduction: Sickle cell disease is the most common monogenetic disorder worldwide. There have been reports of endocrine dysfunction and gonadal failure among affected individuals, especially in males. The findings on ovarian reserve and failure in women with sickle anaemia has been inconsistent.

Aim and objective: The aim of this study was to determine and compare the ovarian reserve of Nigerian women with and without sickle cell anaemia attending a University Teaching Hospital.

Study Design: This cross-sectional study was carried out at the Adult Sickle Cell Clinic and the Community Health Clinic of the Lagos University Teaching Hospital.

Methodology: A total of 166 participants who met the selection criteria, were recruited for the study. The study population consisted of two groups of women matched for age; 83 women with HbSS and 83 women with $\mathrm{HbAA}$. The haemoglobin phenotypes of each participant were determined on alkaline electrophoresis $(\mathrm{pH}$ 8.4) before analysis. serum Anti-Mullerian Hormone (AMH) were determined using Enzyme-linked immunosorbent assay (ELISA) method (Calbiotech Inc. USA, Catalog no AM448T).

Results: The mean \pm SD serum Anti-Mullerian Hormone $(\mathrm{AMH})$ level in women with HbSS $3.64 \pm 0.65$ $\mathrm{ng} / \mathrm{mL}$ was lower than that of women with HbAA $7.35 \pm 1.19 \mathrm{ng} / \mathrm{mL}(p<0.001)$. Serum AMH negatively correlated with age in both study groups ( $\mathrm{HbAA}$ and $\mathrm{HbSS}$ ). Also, a significant negative correlation was found between serum $\mathrm{AMH}$ and $\mathrm{BMI}$ in women with $\mathrm{HbAA}$.

Conclusion: The study showed diminished ovarian reserve in women with HbSS when compared to agematched women with HbAA.

\section{Introduction}

Sickle cell disease (SCD) is an inherited autosomal recessive haemoglobinopathy characterized by chronic haemolytic anaemia.1,2 SCD consists of the haemoglobin SS (HbSS) and haemoglobin variant syndromes such as haemoglobin SC (HbSC), haemoglobin SE (HbSE).3 Sickle cell anaemia (SCA), also known as HbSS, is the most common and most severe form of SCD.4 The prevalence of sickle cell disease ranges between $10-45 \%$ in various parts of sub-Saharan Africa.5,6 Globally, over 300,000 children are born annually with SCD and about $70 \%$ of the births occur in sub-Saharan Africa.7

In Nigeria, it is estimated that $24 \%$ of the population have sickle cell trait,7 making it the country with the largest population of individuals with sickle cell trait worldwide.7 According to Mulumba et al, about 150,000 Nigerian children are born with sickle cell disease annually, 5 in contrast to 250 new SCD births per annum in the United kingdom (UK) and 2000 in the United states (US).6,8 Globally, the life expectancy of women with sickle cell anaemia has improved over the last four decades due to multiple medical advancements in care.6 The survival estimates have continued to improve from a median survival of $42-$ 
48 years in 1994, to 58 years in 2014.10 It is therefore, not unusual nowadays to have patients with SCA who are $60-70$ years old. 11

The implication of people with SCA living longer is that they are inclined to develop complications of the disease. Endocrine complications such as thyroid and gonadal dysfunction may lead to gonadal failure/insufficiency in males and females with undesirable effects on their reproductive health.2,5 Gonadal dysfunction inherent to SCA has been described in adults (especially in males), such as hypogonadism, sperm abnormalities, and erectile dysfunction (ED).12 Although the available literature is inconclusive about gonadal failure in females with $S C A, 11,12$ some reproductive issues that have been reported in females with SCA include delayed puberty 12 and premature menopause.12 Possible explanations

for endocrine dysfunction in patients with SCA include: increased iron storage secondary to frequent blood transfusions, ischemia due to vaso-occlusive crisis and inflammatory mediators during ischemia.8,9 Assessment of ovarian reserve or function is an indicator of the reproductive potential of women. There are various markers available for assessing the ovarian reserve which include: antiMullerian hormone (AMH), basal follicle stimulating hormone (FSH) levels, basal oestradiol (E2), and antral follicle count.14,15 However, serum AMH is considered a novel marker for the assessment of ovarian reserve. $2 \mathrm{AMH}$ is a gonad specific member of the transforming growth factor beta (TGF- $\beta$ ) superfamily with a total weight of $140 \mathrm{KDa} .16,17 \mathrm{It}$ is a dimeric glycoprotein produced by the granulosa cells in the ovary and is usually only seen at the preantral and small antral follicle stages. 18 Serum AMH level is usually determined by the number of basal antral follicles, 18 and does not exhibit intracycle variability, therefore it can be measured on any day of the menstrual cycle, unlike other biochemical markers such as serum basal FSH and estradiol.18,19

Despite the burden of SCD in Nigeria, there is little or no data on the impact of SCA on the ovarian reserve of reproductive-aged women in Nigeria. The aim of this study was to determine and compare the ovarian reserve in Nigerian women with and without SCA using serum AMH as a marker.

\section{Materials And Methods}

This was an analytical cross-sectional study carried out at the Adult Sickle Cell and Community Health Outpatient Clinic of the Lagos University Teaching Hospital (LUTH), Lagos, Nigeria. Ethical approval was obtained from the Health Research Ethics Committee of the Lagos University Teaching Hospital (ADM/DCST/HREC/AP;4P/2674). A total of 166 eligible women who met the selection criteria were recruited for the study between March 2019 and August 2019. The inclusion criteria included nonpregnant women with confirmed HbAA or HbSS phenotype, aged between 18 years and 45 years, and having regular menstruation at the time of the study. Pregnant or lactating women, women with current or past history of oophorectomy/ovarian surgery, combined oral contraceptive usage, chemotherapy and/or radiation therapy, were excluded from the study. The study population consisted of two age matched 
groups based on the haemoglobin phenotype. A total of 83 women with HbSS and 83 women with HbAA were selected for the study.

After obtaining informed written consent, the subjects' weight and height were measured using a portable stadiometer with movable head piece mounted on balanced beam scale (FM -S120 Fullmedia China). Thereafter, five milliliters of venous blood were collected from each participant using sterile needles through venipuncture after disinfection of the antecubital fossa with $70 \%$ alcohol. Two milliliters of the blood were transferred into EDTA bottles for haemoglobin electrophoresis at alkaline pH (8.4) using the electrophoresis machine (DY 300, Hunan, China), while the remaining $3 \mathrm{ml}$ was collected in Serum Separator Tubes (SST) for AMH assay.

The specimen bottles were labelled with the unique identification number and transported via cold chain to the LUTH Central Research Laboratory. The haemoglobin phenotype of all study participants was confirmed before assessing their ovarian reserve. The specimen for $\mathrm{AMH}$ assay was allowed to clot at room temperature for 20 minute and centrifuged at $3500 \mathrm{rpm}$ for 10 minutes using Eppendorf $5415 \mathrm{C}$ centrifuge (Eppendorf AG, Germany). The serum was collected in $2 \mathrm{~mL}$ sterile cryovials and stored at $-800 \mathrm{C}$ until analysis.

The serum levels of Anti-Mullerian Hormones $(\mathrm{AMH})$ were determined using Enzyme-linked immunosorbent assay (ELISA) method (Calbiotech Inc. USA, Catalog no AM448T). The lowest detectable limit of $\mathrm{AMH}$ in this study is $0.15 \mathrm{ng} / \mathrm{mL}$ and the highest detectable limit is $17.00 \mathrm{ng} / \mathrm{mL}$ according to the manufacturer's instruction. Inter-assay precision coefficients of variation were $5.3 \%$ and $3.7 \%$ for level one and two controls, respectively. The intra-assay coefficients of variation were $4.2 \%$ and $3.5 \%$ for level one and two controls, respectively.

\section{STATISTICAL ANALYSIS}

Data were entered and analyzed using the IBM Statistical Package for Social Sciences (SPSS) Version

23.0. Armonk, NY: IBM Corp. The categorical variables were summarized and presented as frequency distribution tables. The test of normality of continuous variables was performed using the KolmogorovSmirnov test. The continuous variables that were normally distributed were presented as mean $( \pm$ standard deviation), The Student's independent t- test was used to compare mean of continuous variables such as age, BMI and serum AMH in HbSS and HbAA study participants. Pearson's correlation coefficient was used to determine the relationship between serum AMH with age and BMI. Simple and multivariable linear regression were used to assess the predictors of serum $\mathrm{AMH}$ using age and $\mathrm{BMI}$ of the study participants as covariates. The level of significance was set at $P<0.05$, power of 0.80 , normal distribution, equal sample size in both groups.

\section{Results}


The mean age $( \pm$ SD) of HbSS study participants at $27.9( \pm 7.5)$ years, did not differ significantly from those of HbAA participants $27.4( \pm 7.9)$ years; $(p=0.959)$. The mean BMI $( \pm S D)$ of HbSS participants $20.7( \pm 3.0) \mathrm{kg} / \mathrm{m} 2$ was significantly higher than $23.6( \pm 4.2) \mathrm{kg} / \mathrm{m} 2$ observed among HbAA participants, as expected (Table 1$)$.

Table 1: Socio-demographic characteristics of the study participants 


\begin{tabular}{|c|c|c|c|c|}
\hline Variable & HbSS & $\mathrm{HbAA}$ & $\mathrm{X} 2$ & P-value \\
\hline & $N=83$ & $N=83$ & & \\
\hline & $\mathrm{n}(\%)$ & $\mathrm{n}(\%)$ & & \\
\hline \multicolumn{5}{|l|}{ Age (year) } \\
\hline$<35$ & $63(75.9)$ & $65(78.3)$ & 0.3065 & 0.959 \\
\hline$\geq 35$ & $20(24.1)$ & $18(21.7)$ & & \\
\hline Mean age (SD) & $27.9( \pm 7.5)$ & $27.4( \pm 7.9)$ & 0.39283 & $0.6950 \ddagger$ \\
\hline \multicolumn{5}{|l|}{ Occupation } \\
\hline Skilled professional & $38(45.8)$ & $32(38.6)$ & 3.5660 & 0.312 \\
\hline Semi-skilled professional & $22(26.5)$ & $29(34.9)$ & & \\
\hline Unskilled professional & $19(22.9)$ & 14(16.9) & & \\
\hline Unemployed & $4(4.8)$ & $8(9.6)$ & & \\
\hline \multicolumn{5}{|l|}{ Tribe } \\
\hline Yoruba & $62(74.7)$ & $58(69.9)$ & 1.6889 & 0.639 \\
\hline Igbo & $10(12.1)$ & 15(18.1) & & \\
\hline Hausa & $1(1.1)$ & $2(2.4)$ & & \\
\hline Other & $10(12.1)$ & $8(9.6)$ & & \\
\hline \multicolumn{5}{|l|}{ Parity } \\
\hline 0 & $69(83.1)$ & 64(77.1) & 3.0526 & 0.217 \\
\hline$\geq 1$ & $14(16.9)$ & $19(22.9)$ & & \\
\hline \multicolumn{5}{|l|}{ Alcohol intake } \\
\hline Yes & $27(32.5)$ & 28(33.7) & 0.0272 & 0.869 \\
\hline No & $56(67.5)$ & $55(66.3)$ & & \\
\hline \multicolumn{5}{|l|}{ Cigarette smoking } \\
\hline Yes & $2(2.4)$ & $1(1.2)$ & 0.3395 & 0.560 \\
\hline No & $81(97.6)$ & $82(98.8)$ & & \\
\hline \multicolumn{5}{|l|}{ BMI (kg/m2) } \\
\hline$<25$ & $75(90.4)$ & $50(60.2)$ & 23.094 & $<0.001^{*}$ \\
\hline$\geq 25$ & $8(9.6)$ & $33(39.8)$ & & ;8 \\
\hline
\end{tabular}




\begin{tabular}{|lllll|} 
Mean BMI $( \pm$ SD $)$ & $20.7( \pm 3.0)$ & $23.6( \pm 4.2)$ & .0349 & $<0.001 * \neq 0.736$ \\
Hydroxyurea & $5(6.0)$ & - & 0.665 & \\
& $78(94.6)$ & - & \\
\hline $\begin{array}{l}\text { \# Student t-test statistic, } \\
\text { * Statistically significant }\end{array}$ & & & \\
\hline
\end{tabular}

Table 2: Shows mean distribution of serum AMH levels among study participants. The mean serum AMH levels in the study participants with HbSS phenotype $(3.64 \pm 0.65 \mathrm{ng} / \mathrm{mL})$ when compared to $(7.35 \pm$ $1.19 \mathrm{ng} / \mathrm{mL})$ in study participants with HbAA phenotype was significantly lower $(p<0.001)$. Similarly, significantly lower values of serum AMH $(0.15-1.14 \mathrm{ng} / \mathrm{mL})$ were demonstrated among female participants with HbSS compared to HbAA participants $(21.7 \%$ vs $10 \% ; \chi 2=9.963, p=0.007)$.

Table 2

Comparison of serum AMH levels between $\mathrm{HbSS}$ and $\mathrm{HbAA}$ study participants

\begin{tabular}{|lllll|}
\hline AMH categories $(\mathrm{ng} / \mathrm{mL})$ & HbSS $(\mathbf{N}=\mathbf{8 3}) \mathbf{n}(\%)$ & \multicolumn{2}{l|}{$\begin{array}{l}\text { HbAA (N=83) } \\
\text { n (\%)X2P-value }\end{array}$} & \\
\hline Low (0.15-1.14) & $18(21.7)$ & $9(10.8)$ & 9.963 & $0.007^{*}$ \\
\hline Normal (1.15-2.56) & $14(16.9)$ & $5(6.0)$ & & \\
\hline High (>2.65) & $51(61.4)$ & $69(83.1)$ & & \\
\hline Mean (SD) & $3.64(0.65)$ & $7.35(1.19)$ & $-5.398 \ddagger$ & $<0.001^{*}$ \\
\hline fstudent's t test, * Statistically significant & & & \\
\hline
\end{tabular}

Table 3 shows a negative correlation between serum AMH levels and age in both $\mathrm{HbSS}(r=-0.255 ; p=$ $0.020)$ and HbAA study participants $(r=-0.425 ; p<0.001)$. Conversely, while BMI showed a weak but significant negative correlation with AMH levels among HbAA subjects $(r=-0.240$, P-value $=0.029)$, no significant correlation was observed between BMI and AMH among HbSS participants $(r=0.035$, $p$-value $=0.733)$.

Table 3

Correlation analysis of serum $\mathrm{AMH}$ and age/body mass index of HbSS and HbAA study participants

\begin{tabular}{|lllll|}
\hline Variable & HbSS & \multicolumn{3}{c|}{ HbAA } \\
\hline & $\mathbf{R}$ & P-value & $\mathbf{R}$ & P-value \\
\hline Age & -0.255 & 0.020 & -0.425 & $<0.001^{\star}$ \\
BMI & 0.035 & 0.733 & -0.240 & 0.029 \\
\hline
\end{tabular}


In Table 4, the HbSS phenotype status and age of participants were significant independent predictors of serum AMH levels $(p<0.001)$ after univariate linear regression modelling.

Table 4 Regression analysis of the predictors of serum anti-Mullerian Hormone participants with HbSS and HbAA

\begin{tabular}{|c|c|c|c|c|c|c|}
\hline \multirow[t]{2}{*}{ Variables } & \multicolumn{3}{|c|}{ Simple linear regression } & \multicolumn{3}{|c|}{ Multiple linear regression } \\
\hline & 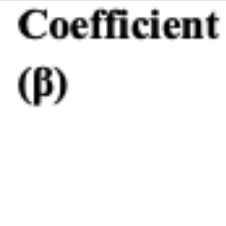 & $\begin{array}{l}95 \% \text { Confidence } \\
\text { interval }\end{array}$ & P-value & $\begin{array}{l}\text { Adjusted } \\
\text { Coefficient } \\
\text { (adjusted } \\
\text { ß) }\end{array}$ & $\begin{array}{l}95 \% \\
\text { Confidence } \\
\text { interval }\end{array}$ & P-value \\
\hline HbSS & -4.24 & -5.68 to -2.80 & $<0.001^{*}$ & -4.42 & -5.88 to -2.96 & $<0.001^{*}$ \\
\hline $\begin{array}{l}{ }^{{ }^{B}} \mathbf{B M I} \\
\left(\mathrm{Kg} / \mathrm{m}^{2}\right)\end{array}$ & -0.02 & -0.07 to 0.03 & 0.457 & -0.02 & -0.06 to 0.03 & 0.436 \\
\hline $\begin{array}{l}\text { Age } \\
\text { (years) }\end{array}$ & -0.19 & -0.29 to -0.08 & $<0.001^{*}$ & -0.18 & -0.28 to -0.08 & $<0.001^{*}$ \\
\hline
\end{tabular}

\$ BMI: Body Mass Index, * statistically sighificant at P-value $<0.05$, Reference: HBAA

\section{Multivariate regression analysis}

Haemoglobin $(\mathrm{Hb})$ phenotype and serum AMH: After controlling for potential confounding variables (such as age, and $\mathrm{BMI}$ ), we found that on the average the serum $\mathrm{AMH}$ level was about $4.42 \mathrm{ng} / \mathrm{mL}$ less among HbSS participants as compared to HbAA participants (adjusted $\beta=-4.42,95 \% \mathrm{Cl}$ : -5.88 to -2.96 , P-value $<0.001)$.

Age and AMH: After controlling for confounding variables (such as $\mathrm{Hb}$ phenotype status and $\mathrm{BMI}$ ), we found that for every yearly increase in age, the serum AMH level decreased by $0.18 \mathrm{ng} / \mathrm{mL}$ among participants (adjusted $\beta=-0.18,95 \% \mathrm{Cl}:-0.28$ to -0.08 , P-value $<0.001$ )

\section{Discussion}

This study aimed to determine and compare the ovarian reserve among Nigerian women with $\mathrm{HbSS}$ and those with $\mathrm{HbAA}$, using serum $\mathrm{AMH}$ as a marker, in order to document the impact of haemoglopinothies on the reproductive health of affected women. The exhaustive literature search suggest that this is the first and larger study to utilize serum $\mathrm{AMH}$ to evaluate ovarian reserve among $\mathrm{HbSS}$ women within the age range of 18-45 years in Nigeria and SubSaharan Africa to the best of my knowledge. 
This study found that the mean serum levels of AMH among women with HbSS was significantly lower than the mean serum AMH levels among women with $\mathrm{HbAA}$. This result is in agreement with the findings by Kopeika et al in United Kingdom,20 that reported a mean AMH of $7.6 \mathrm{pmol} / \mathrm{L}(1.06 \mathrm{ng} / \mathrm{mL})$ among $\mathrm{HbSS}$ participants as compared to a value of $13.4 \mathrm{pmol} / \mathrm{L}(1.88 \mathrm{ng} / \mathrm{mL})$ among $\mathrm{HbAA}$ participants. The similarity in our study and that of Kopeika et al may be explained by the fact that both studies recruited participants with similar characteristics and restricted the age limit of study participants to the reproductive age group. In contrast, Ibrahim and co-workers reported no significant differences in mean concentration of serum AMH between sickle cell disease participants and non-sickle cell disease participants. 2 The study by Ibrahim et al recruited participants between the ages of 2 years and 38 years. The inclusion of the pre-pubertal participants could have significant impact on their findings as serum $\mathrm{AMH}$ levels are low in children and adolescent girls.14

This study revealed that a significantly higher proportion of HbSS participants had low serum AMH levels compared with age matched HbAA participants. Similarly, the proportion of participants with high serum $\mathrm{AMH}$ value was also found to be higher in $\mathrm{HbAA}$ as compared to HbSS study participants. This may imply diminished ovarian reserve among HbSS study participants. The finding is similar to a previous study, which reported that the women with $\mathrm{HbAA}$ had a higher $\mathrm{AMH}$ levels compared to women with SCD.20

Subgroup analyses of the relationship between serum AMH and age in $\mathrm{HbSS}$ and $\mathrm{HbAA}$ participants, showed significant negative correlations between serum AMH levels and the age in both study groups. Our finding is consistent with the finding of negative correlation observed between the serum AMH and age of infertile women by Scheffer et al.21 Our finding is also similar to the result of a large retrospective study consisting of 219,227 Asian Indian women aged 18-50 years which reported a negative correlation between the serum AMH levels and age.22

In this study, there was a statistically significant difference in the mean BMI of the two groups of participants. The observed difference in BMI is likely due to the haemoglobinopathy and its long-term effect on growth and development. Although a negative correlation was observed between $\mathrm{AMH}$ and $\mathrm{BMI}$ in the HbAA, the study found no correlation between serum AMH level and BMI among the HbSS study participants. The latter is similar to findings in previous studies by Zahra et al,23 and Buyuk et al.24 which showed no significant linear relationship between BMI and serum AMH levels in women of reproductive-age group. The possible explanation for this finding may be the higher proportion $(90.4 \%$ versus $60.0 \%)$ ) of $\mathrm{HbSS}$ study participants to $\mathrm{HbAA}$ study participants who had low or normal $\mathrm{BMI}$ at enrollment.

All the participants from both groups in this study were of African race, but from different ethnic backgrounds in Nigeria. The predominant ethnic group of our participants was Yoruba. The strength of this study includes: cross-sectional study involving a large population of women sickle cell anaemia within the reproductive age-group. 


\section{Limitations of the Study}

Firstly, the study was hospital-based therefore the finding may not be a true representation of the general public but has enough power to make generalization. Secondly. the possibility of primary ovarian insufficiency/premature ovarian failure cannot be completely excluded as serum oestrogen and serum pituitary gonadotropins (FSH and LH) were not assayed. However, all study participants were still having regular menstruation at the time of enrolment into the study. Also, the antral follicular count, serum FSH and inhibin B were not measured and the subjects were not fully evaluated for polycystic ovarian syndrome, a disorder associated with abnormally high serum AMH. However, attempt was made at recruitment to exclude women with menstrual disorders, using the screening form.

\section{Conclusion}

Women living with Sickle cell anaemia may be at risk of diminished ovarian reserve and by extension, reduced reproductive ability.

\section{Declarations}

\section{Ethical approval and consent to participate}

The study was approved by the Health Research Ethics Committee of the Lagos University Teaching Hospital (ADM/DCST/HREC/AP;4P/2674) and an informed written consent was obtained from each of the study participant before enrollment into the study.

\section{Consent for publication}

"Not applicable"

\section{Availability of data and materials}

The data that support the findings of this study are available from SRG but restrictions apply to the availability of these data, which were used under license for the current study, and so are not publicly available. Data are however available from the authors upon reasonable request and with permission of CCM.

\section{Competing interest}

The authors declare that they have no competing interests

\section{Funding}

The study was funded by the researchers.

\section{Authors' contributions}


SRG, ASP, and CCM conceptualized the research idea and wrote the draft study protocol. All the authors approved the final study protocol. OOK, ASP, AUA, and SRG counselled study participants, obtained informed consent, recruited participants, and participated in data collection. SRG, ASP, AUA, and CCM funded the project. OVO and SRG performed the laboratory analysis. SRG, CCM, and OVA performed the data entry and statistical analysis. CCM and BBA supervised the entire research. All authors reviewed and approved the final manuscript for publication.

\section{Acknowledgements}

Dr Adeleke Yusuf for data collection

Dr Kite Omoru for data collection

Dr Awosika Oluwakorede lyanuoluwa for data collection, and analysis

Mr. Roosevelt Anyanwu for participating in laboratory procedure and data analysis.

\section{Abbreviations}


AFC: $\quad$ Antral follicle count

AMH: Anti-Mullerian Hormones

AOR: Assessment of Ovarian Reserve

BMI: $\quad$ Body mass index

DOR: Diminished ovarian reserve

E2: $\quad$ Basal oestradiol

ED: $\quad$ Erectile dysfunction

EDTA: Ethylenediaminetetraacetic acid

ELISA: Enzyme-linked immunosorbent assay

FSH Basal follicle stimulating hormone

GnRH: Gonadotropin- releasing hormones

$\mathrm{Hb} \mathrm{A}: \quad$ Adult Haemoglobin

$\mathrm{Hb} \mathrm{S:} \quad$ Sickle Haemoglobin

HbAA: Haemoglobin AA

HbSC: Haemoglobin SC

HbSD: Haemoglobin SD Punjab disease

HbSE: Haemoglobin SE

HbSO: Haemoglobin SO Arab disease

HbSS: Haemoglobin SS Phenotype

$\mathrm{HbS} \beta+$ : Haemoglobin S-beta-Thalassemia plus

HbS $\beta 0$ : Haemoglobin S-beta-thalassemia zero

Kg: Kilograms

LH: Luteinizing hormone

LUTH: $\quad$ Lagos University Teaching Hospital

ML: $\quad$ Milliliters

$\mathrm{ng} / \mathrm{ml} \quad \quad$ Nanograms per milliliter

OR: $\quad$ Ovarian Reserve 


\begin{tabular}{ll}
\hline pg/L: & Picograms per liter \\
\hline SCA: & Sickle cell anaemia \\
\hline SCD: & Sickle cell disease \\
\hline SPSS: & Statistical package for the social sciences \\
\hline SST: & Serum Separator Tubes \\
\hline TGF- $\beta$ : & Transforming growth factor beta \\
\hline U/L: & International unit per litre \\
\hline UK: & United Kingdom \\
\hline US: & United States \\
\hline WHO: & World Health Organization
\end{tabular}

\section{References}

1. Ozen S, Unal S, Erçetin N, Taşdelen B. Frequency and risk factors of endocrine complications in Turkish children and adolescents with sickle cell anaemia. Turk J Hematol. 2013;30(1):25-31.

2. Ibrahim MA, Siddiq-Fgeer SA, Elhassan TH, Mohamed-Salih FE, Babiker AE, Ahmaed AY, et al. The influence of Sickle Cell Anaemia on LH, FSH, AMH, Estradiol, Vitamin D and Ferritin levels of Sudanese females. Am J Innov Res Appl Sci. 2017;4(1):15-21.

3. Stimpson S, Rebele EC, DeBaun MR. Common gynaecological challenges in adolescents with sickle cell disease. Expert Rev Hematol. 2016;9(2):187-96.

4. Ndeezi G, Kiyaga C, Hernandez AG, Munube D, Howard TA, Ssewanyana I, et al. Burden of sickle cell trait and disease in the Uganda sickle surveillance study (US3): a cross- sectional study. Lancet Glob Health. 2016;4:195-200.

5. Mulumba LL, Wilson L. Sickle cell disease among children in Africa: an integrative literature review and global recommendations. Int J Afr Nur Sci. 2015;1(3):56-64.

6. Brewin J, Howard J. Sickle cell disease: an update on management. Paediatrics Child Health. 2017. http://dx.doi.org/10.1016/j.paed.2017.07.005.

7. National guideline for. the control and management of sickle cell disease. FMOH Nigeria 2014.

8. Nahata L, Caltabellotta NM, Ball K, O'brien SH, Creary SE. Desire for parenthood and reproductive health knowledge in adolescents and young adults with sickle cell disease and their caregivers. Pediatr Blood Cancer. 2018;65(2):e26829.

9. Hagag AA, El-Farargy MS, Elrefaey S, Abo El-enein AM. Study of gonadal hormones in Egyptian female children with sickle cell anaemia in correlation with iron overload: Single centre study. Hematol Oncol Stem Cell Ther. 2016;9(1):1-7. 
10. Thein MS, Thein SL. World sickle cell day 2016: A time for appraisal. Indian J Med Res. 2016;143(6):678-81.

11. Ballas SK. Pathophysiology and principles of management of the many faces of the acute vasoocclusive crisis in patients with sickle cell disease. Eur J Haematol. 2015;95(2):113-23.

12. Ghafuri DL, Stimpson S, Day ME, James A, DeBaun MR, Sharma D. Fertility challenges for women with sickle cell disease. Expert Rev Hematol. 2017;10(10):891-901.

13. Cohen J, Chabbert-Buffet N, Darai E. Diminished ovarian reserve, premature ovarian failure, poor ovarian responder - a plea for universal definitions. J Assist Reprod Genet. 2015;32(12):1709-12.

14. Lunsford AJ, Whelan K, McCormick K, McLaren JF. Antimullerian hormone as a measure of reproductive function in female childhood cancer survivors. Fertil Steril. 2014;101(1):227-31.

15. Pfeifers S, Butts S, Dumestic O, Fossum G, Guidice L, Gracia C, et al. Testing and interpreting measures of ovarian reserve: a committee opinion. Practice Committee of the American Society for Reproductive Medicine. FertilSteril. 2015;103(3):e9-17.

16. Ramalho de Carvalho $B$, Gomes Sobrinho DB, Vieira AD, Resende MP, Barbosa AC, Silva AA, et al. ovarian reserve assessment for infertility investigation. ISRN Obstet Gynecol. 2012;2:1-5.

17. Kalaiselvi VS, Krishna GP. The antimullerian hormone- a novel marker for assessing the ovarian reserve in women with regular menstrual cycles. J Clin Diagn Res. 2012;6(10):1636-9.

18. Amanvermez R, Tosun M. An update on ovarian aging and ovarian reserve tests. Int J FertilSteril. 2016;9(4):411-5.

19. Smith-Whitley K. Reproductive issues in sickle cell disease. Am Soc Hematol Educ Program. 2014; $2014(1): 418-24$.

20. Kopeika J, Oyewo A, Punnialingam S, Reddy N, Khalaf Y, Howard J, et al. Ovarian reserve in women with sickle cell disease. PLoS ONE. 2019;14(2):e0213024.

https://doi.org/10.1371/journal.pone.0213024.

21. Scheffer JAB, Scheffer B, Scheffer R, Fabio Florencio F, Grynberg M, Lozano DM. Are;8 age and antiMullerian hormone good predictors of ovarian reserve and response in women undergoing IVF? JBRA Assist. Reprod. 2018;22(3):216-20.

22. K K, lyer S, Sinkar P, Velumani A. Anti-Mullerian Hormone (AMH) and Age - An Indian laboratory retrospective analysis. Asian J Health Sci. 2019;5(1):7. 1-8.

23. Heidar Z, Bahramzadeh S, Motevasselian M, Zamirnazari B. the relationship between body mass index (BMI) and serum anti-mullerian hormone (AMH) levels. Acta Medica Mediterranea. 2018;34:329-34.

24. Buyuk E, Seifer DB, Illion E, Grazi RV, Lieman H. Elevated body mass index is associated with lower serum antimullerian hormone levels in infertile women with diminished ovarian reserve but not with normal ovarian reserve. J fertnstert. 2011;95(7):2364-68. 